\title{
A Review: Is Ginger (Zingiber officinale var. Roscoe) Potential for Future Phytomedicine?
}

\author{
Dina Mulyana Syafitri ${ }^{1,2}$, Jutti Levita ${ }^{1}$, Mutakin Mutakin ${ }^{3}$, Ajeng Diantini ${ }^{1}$ \\ ${ }^{1}$ Department of Pharmacology and Clinical Pharmacy \\ Faculty of Pharmacy, Universitas Padjadjaran, Indonesia \\ ${ }^{2}$ Riau Islands General Hospital \\ Tanjungpinang, Riau Islands, Indonesia \\ ${ }^{3}$ Department of Pharmaceutical Analysis and Medicinal Chemistry \\ Faculty of Pharmacy, Universitas Padjadjaran, Indonesia \\ E-mail korespondensi : inacm/2002@yahoo.com
}

\begin{abstract}
Zingiber officinale Roscoe (red:ginger), one of the most widely consumed herbs in Asia, has been empirically used to treat various disorders in Indonesia. There are three known types of ginger: giant ginger or white ginger (Zingiber officinale var. Roscoe), small white ginger or ginger emprit (Zingiber officinale var. Amarum), and red ginger (Zingiber officinale var. Rubrum). The main components of ginger rhizome are carbohydrates, lipids, essential oils, terpenes, and phenol compounds such as gingerol (23-25\%) and shogaol (18-25\%). Many studies had confirmed beneficial effects of ginger against inflammation, free radicals, diabetes mellitus, bacterial infection, cancer, nausea, etc. Z. officinale var. Roscoe is considered a safe herbal with not significant adverse effects. This plant is potential to be developed for future phytomedicine, however further explorations on its clinical studies in humans is expected, especially the efficacy and safety of the risk of side effects.
\end{abstract}

\section{Introduction}

Zingiber officinale is one of the most widely used plants in Asia, Australia and many other countries. ${ }^{1,2,3,5,12}$ Empirically, Z. officinale has been used in digestive disorders (indigestion, flatulence, constpation, nausea), headache, rheumatism, cold and cough. $^{6}$

In the last few decades, $Z$. officinale is extensively studied for its medicinal properties by advanced scientific techniques and a variety of bioactive compounds had been isolated from different parts of the plant. The plant is reported for antimicrobial activity, anticancer activity, antioxidant activity, antidiabetic activity, nephroprotective activity, hepatoprotective activity, larvicidal activity, analgesic activity, anti-inflammatory activity and immunomodulatory activities. ${ }^{1,8,9,12,13}$

More than seventy pharmacology studies of $Z$. officinale rhizomes have been reported. Most of the secondary metabolites of herbs are commercially important and find use in a number of pharmaceutical compounds. Flavonoids and phenolics are the most important groups of secondary metabolites and bioactive compounds in plants. ${ }^{9}$ Shogaol and gingerol are the most common bioactive compounds found in ginger, and have various pharmacological benefits.

The present review is focused for the taxonomy, distribution, botanical description, secondary metabolite extraction, chemical constituents, pharmacological activity, side effect and toxicity of $Z$. officinale var Roscoe.

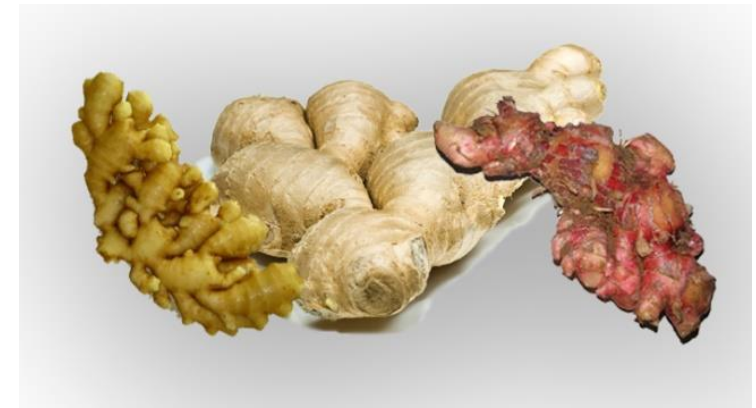

Figure 1: Rhizome of Zingiber officinale var. Amarum (left), Zingiber officinale var. Roscoe (center), and Zingiber officinale var. Rubrum (right). ${ }^{33}$

$\begin{array}{ll}\text { Taxonomy, Distribution, and Botanical Description } \\ \text { Kingdom } & \text { : Plantae } \\ \text { Division } & \text { : Magnoliophyta } \\ \text { Class } & : \text { Liliopsida } \\ \text { Order } & \text { : Zingiberales } \\ \text { Family } & \text { : Zingiberaceae } \\ \text { Genus } & \text { : Zingiber } \\ \text { Species } & \text { : Zingiber officinale var. Roscoe } \\ \end{array}$

Ginger is a tropical plant, grows well in hot and humid climates. The plant is cultivated in China, Nepal, US, India, Bangladesh, Taiwan, Jamaica, Nigeria and Indonesia. India is the biggest producer of Z. officinale. ${ }^{8}$ In Indonesia, $Z$. officinale is one of the export commodities, with the development area in 2010 reaching 6,053 ha and the requirement of ginger seed is rhizome 12.106 tons/year. In accordance with the requirements of growing ginger, seed production sites 
can be selected on land with climate type $A, B$, or $C$, with altitude of $300-900 \mathrm{dpl}$, average temperature $25-30^{\circ} \mathrm{C}$, wet month number 7-9 months, rainfall 2,500-4,000 $\mathrm{mm}$ /year, with light intensity $70-100 \% .^{14}$

Ginger is herbaceous rhizomatous perennial, reaching up to $90 \mathrm{~cm}$ in height under cultivation. Rhizomes are aromatic, thick lobed, pale yellowish, bearing simple alternate distichous narrow oblong lanceolate leaves. The herb develops several lateral shoots in clumps, which begin to dry when the plant matures. Leaves are long and $2-3 \mathrm{~cm}$ broad with sheathing bases, the blade gradually tapering to a point. Inflorescence solitary, lateral radical pedunculate oblongcylindrical spikes. Flowers are rare, rather small, calyx superior, gamosepalous, three toothed; open splitting on one side, corolla of three sub equal oblong to lanceolate connate greenish segments. ${ }^{11}$ Stems erect. The leaves are often clear 2 rows with stem hugging, and tongue between the borders and leaf blades. Zygomorph flowers are bandaged. Petals forms as tube, with a tip hammered, often split in a midrib. Rhizome slightly flat, bagin tip short and flat branches, at each end of the branch there is a grooved curve inside. The outer pieces are yellowish brown, grooved lengthwise. ${ }^{15}$

\section{Extraction Method}

Secondary metabolite compounds are organic compounds derived from plants that have bioactive ability, for example phenolic, flavonid and terpenoid groups. A number of chemical and physical factors that could influence secondary metabolism in plant cell cultures have been found, including light, temperature, $\mathrm{pH}$ of medium, aeration, cell density, etc. Different light intensities are able to change synthesis of phenolics and flavonoids components in ginger. ${ }^{16,17}$

The phenolic compounds represent one of the main groups of secondary metabolites in plants and they are present in foods and nutraceutics. These phytochemicals have a wide range of biological actions, including the ability to act as antioxidants, ameliorate inflammation, modulate enzyme activity, and regulate gene expression. The content of total polyphenolics in ginger extract was in amount of $181.41 \mathrm{mg} / \mathrm{g}$ ginger extract, and flavonoid in amount of $14.15 \mathrm{mg} / \mathrm{g}$ ginger extract. $^{26}$

Flavonoids are important in plant biochemistry and play an important role in plant physiology, acting as antioxidants, enzyme inhibitors, pigments and light screens. ${ }^{17}$ HPLC analysis revealed that the synthesis of flavonoids such as quercetin, catechin, epicatechin and naringenin were enhanced under low light intensity. A decreasing of light intensity also reduced the photosynthesis rate, and consequently diminished the soluble carbohydrate and plant biomass in Halia Bentong and Halia Bara. ${ }^{17}$

Drying of ginger rhizome should be done below $70{ }^{\circ} \mathrm{C}$ for better quality dried products. For glycoside species, a maximum temperature of $100{ }^{\circ} \mathrm{C}$ is recommended, for mucilage species $65{ }^{\circ} \mathrm{C}$ and for essential-oil species 35 to $45^{\circ} \mathrm{C} .{ }^{19}$

A study has been done to compare between decoct and maceration methods using water and ethanol as the solvent to extract flavonoid and phenolic contents. The ginger was oven-dried at $50^{\circ} \mathrm{C}$ and macerated in ethanol ( $10 \mathrm{~g}$ in $100 \mathrm{ml}$ ) for $3 \times 24$ hours and 48 hours. The other sample was decocted in distilled water for 24 and 48 hours. Both of the solvents were rotavaporated. ${ }^{22}$ The ethanol extract is more active ${ }^{20,22}$ than the others although its total flavonoid and phenols are lower. Water extract contains higher total flavonoid and phenols. ${ }^{22}$ Traditionally, the extraction of 6-gingerol and 6-shogaol compounds is accomplished by reflux or Soxhlet extraction. However, prolonged extraction at high temperature may degrade the 6-gingerol and 6-shogaol compounds and involves high energy cost. In acidic media and under high extraction temperature 6-gingerol can be degraded to 6-shogaol. The optimum extraction condition for all responses was at $76.9{ }^{\circ} \mathrm{C}$ for $3.4 \mathrm{~h}$. Pharmaceutical quality of ginger could be improved significantly by optimizing of extraction process. ${ }^{28}$

\section{Chemical Constituent}

The most important compounds responsible for ginger's therapeutic activities, are divided into nonvolatile and volatile compounds. The non-volatile fraction consists of an oleoresin. Elements responsible for gingers spicy flavor have been identified as the gingerols. The composition of the volatile fraction consists mainly of sesquiterpene derivatives, responsible for the aroma. Such compounds include (-)zingiberene, (+)-curcumene, (-)- $\beta$-sesquiphelandrene and $\beta$-bisabolene. The monoterpene derivatives are also a part of this essential oil. ${ }^{16,21}$

Z. officinale rhizome contains $1-4 \%$ essential oil and oleoresin, but the chief constituent is sesquiterpene (53.57\%). ${ }^{30}$ Several compounds have been identified in the essential oil, it's estimated that there are 28 compounds. The most content were eudesmol (8.19\%), $\gamma$-terpinene $(7.88 \%), \alpha$-curcumene (7.28\%), zingiberene (6.06\%), alloaromadendrene (6.56\%), $\alpha$-pinene $(5.76 \%), \delta$-cadinene $(3.84 \%)$, elemol (3.39\%), farnesal (3.45\%), E- $\beta$-farnesene $(3.57 \%)$, neril acetate $(2.8 \%)$ and $\beta$-myrcene $(2.94 \%){ }^{32}$

The main constituents of ginger are sesquiterpenoids with zingiberene as the main component. Other components include $\beta$ sesquiphellandrene, bisabolene and farnesene, which are sesquiterpenoids, and trace monoterpenoid fraction, (cineol, citral and $\beta$-sesquiphellandrene). ${ }^{20}$

The gingerols is the primary active constituents, 5-hydroxy-1-(4-hydroxy-3-methoxy phenyl) decan-3-one is the most abundant in this constituent. Some other active compounds are mono and sesquiterpenes; camphene, betaphellandrene, curcumene, cineole, geranyl acetate, terphineol, 
terpenes, borneol, geraniol, limonene, linalool, alphazingiberene (30-70\%), sesquiphellandrene (15-20\%), betabisabolene (10-15\%) and alpha-farmesene. Its Bulb is widely used because it contains gingerol, ethanol as active chemical compound. It also contains amadaldehyde, paradols, gingerdiols, gingerdiacetates, gingerdiones, 6-gingersulfonic acid, gingerenones. ${ }^{21}$

Gingerol very unstable in the presence of heat and high temperatures will turn into shogaol. Shogaol which is spicier than gingerol, is the main component of dry ginger. ${ }^{22}$ Gingerols are thermally labile due to the presence of a b-hydroxy keto group in the structure and undergo dehydration readily to form the corresponding shogaols. ${ }^{31}$ Kinetics of [6]-gingerol degradation was characterized by least square fitting of a rate equation. It was found that gingerol exhibited novel reversible kinetics, in which it undergoes dehydration-hydration transformations with shogaol, the major degradation product. Degradation rates were found to be $\mathrm{pH}$ dependent with greatest stability observed at $\mathrm{pH} 4$. The reversible degradation of [6]-gingerol at $100{ }^{\circ} \mathrm{C}$ and $\mathrm{pH}$ 1 was relatively fast and reached equilibrium within $2 \mathrm{~h}$. Rapid degradation of gingerol mainly occurs at high temperature and at an acidic $\mathrm{pH}$, resulting in dehydration to form shogaol. Both gingerol and shogaol are most stable at $\mathrm{pH} 4$ at $37^{\circ} \mathrm{C} .{ }^{18}$

The presence of a b-hydroxy keto functional group in the structure of gingerols is a key feature that makes them thermally labile and makes them undergo facile dehydration at high temperature and in acidic conditions. A kinetic study of the dehydration of [6] gingerol was carried out at $120^{\circ} \mathrm{C}$ over a $\mathrm{pH}$ range from 2.4 to 7.2. These studies showed that the dehydration of gingerol was $\mathrm{pH}$ and temperature dependent and followed first order kinetics. The mechanism of degradation of gingerol was considered in previous studies, including a retro-aldol reaction leading to formation of zingerone and aliphatic aldehydes, and dehydration to shogaol. Polymerization of shogaol was also demonstrated at higher temperature $\left(120^{\circ} \mathrm{C}\right)$ in 12 h. ${ }^{18}$

In terms of lipophilic properties, [6]-shogaol is considerably more lipophilic than [6]-gingerol as a result of the loss of a hydroxyl group from gingerol on dehydration to shogaol. The difference in the lipophilicity would result in significant differences in bioavailability and pharmacokinetic parameters of these two compounds in vivo. ${ }^{18}$

\section{Pharmacology Activity}

The primary activities include antiinflammatory, antioxidant, analgesic effect, antiproliferative and hepatoprotective activity. ${ }^{21}$

\section{Antiinflammatory Activity}

First group to investigate the effect of ginger on platelet aggregation by using four ginger extracts, produced using different solvents (aqueous, n-hexane, chloroform, and ethyl acetate). They reported that ginger inhibited platelet aggregation using arachidonic acid (AA), epinephrine, adenosine diphosphate (ADP), and collagen as agonists. Others have corroborated this, reporting that certain ginger compounds inhibit in vitro platelet aggregation when using a variety of agonists (AA, collagen, platelet activating factor, and thrombin). This reduction in platelet aggregation was most potent when AA was used as the agonist, requiring lower concentrations to cause inhibition when compared to the other agonists. ${ }^{24}$

While few studies investigating the effect of ginger and its compounds on the clotting cascade have been undertaken, a considerable amount of in vitro research suggests that ginger compounds interact with AA-derived eicosanoid and thromboxane synthesis. The AA cascade can produce the eicosanoids involved in inflammation (i.e. prostaglandin E2) as well as thromboxane, which is amongst the many agonists of platelet aggregation. Numerous studies indicate that ginger extract and particular ginger compounds inhibit products specific to the cyclooxygenase pathway, including a reduction in thromboxane B2 (TxB2) production prostaglandin formation (PGF2a, PGE2, and PGD2), and cyclooxygenase enzyme activity. These same compounds also interact with the lipoxygenase pathway, including reductions in 5-lipoxygenase enzyme activity. ${ }^{24}$

Finally, ginger compounds might also inhibit the activity of phospholipase A2, which suggests that ginger exerts its anti-platelet aggregating as well as its potential anti-inflammatory actions through interaction with one of the initial steps in this pathway. Due to the observed in vitro effects of ginger on the AA cascade, excessive bleeding and interactions with platelet therapy during cancer chemotherapy are of clinical concern. While the results of in vitro studies are consistent, these results are not always translatable to the complex human system. Due to the potential effects of ginger on platelet aggregation, ginger is a commonlycited example of an herbal supplement that should be avoided in patients with thrombocytopenia, platelet function defects or coagulopathy, such as populations using ginger for its antiemetic effect in cancer chemotherapy. ${ }^{24}$

\section{Antioxidant Activity}

Oxidation of biological molecules induces a variety of pathological disease including atherosclerosis or cancer. These damages are caused due to the presence of free radicals. [6]-gingerol, [6]-shogaol have displayed strong antioxidant activity in vitro. It is known that the antioxidant activity of plant extracts containing polyphenol components is due to their capacity to be donors of hydrogen atoms or electrons and to capture the free radicals. The ginger extract showed antioxidant effect in inhibiting DPPH radical, IC50 was $4.25 \mathrm{mg} / \mathrm{ml}$. DPPH analysis is one of the tests used to prove the ability cof the components of the ginger extract to act 
as donors of hydrogen atoms. DPPH radical does not react with flavonoids, which contain no $\mathrm{OH}$-groups in $\mathrm{B}$ ring as well as with aromatic acids containing only one OH-group. ${ }^{25}$

\section{Antidiabetic Activity}

A double-blind, placebo-controlled, randomized clinical trial was conducted on 20-60 year old patients with type 2 diabetes who did not receive insulin. Participants in the intervention and control groups were received $3 \mathrm{~g}$ of powdered ginger or placebo (lactose in capsules) daily for 3 months. This report shows that the 3 months supplementation of ginger improved glycemic indices, total antioxidant capacity (TAC) and paraoxonase-1 (PON-1) activity in patients with type 2 diabetes (T2DM). In this study, $3 \mathrm{~g} /$ day of ginger supplementation in T2DM patients for 3 months significantly decreased glucose, insulin, insulin resistance, highsensitive C-reactive protein (hs-CRP) and malate dehydrogenase (MDA) but significantly increased PON-1 and TAC compared to the control group. ${ }^{27}$

\section{Antibacteria}

Ginger extract has showed antimicrobial activity against broad spectrum of pathogenic microorganisms such as Escherichia coli, Salmonella typhi, Bacillus subtilis and yeast Candida albicans. Main components, including [6]-gingerol and [12]-gingerol, isolated from ginger rhizome displayed antibacterial activity against periodontal bacteria. Hiserodt (1998) mentioned in his research that [10]-gingerol is active inhibitor of Mycobacterium avium and $M$. tuberculosis. $^{25}$ Ethanolic extract of ginger is best effective against $S$. aureus when compared with $E$. feacalis. $^{20}$

\section{Cytotoxic Activity}

Except for antioxidant and antimicrobial effects of phenolic compounds contained in Zingiber officinale, these components also have anticarcinogenic and anti-mutagenic activities. [6]-gingerol inhibits cell adhesion, invasion, motility and activities of human breast cancer cell lines. ${ }^{25}$

\section{Antinausea/Antiemetic}

The volatile oil of ginger known have antiemetic potency. The compounds as terpinolene, $\beta$ pinene and $\alpha$-phellandrene known had interact with 5$\mathrm{HT}_{3}$ receptor channel system and antispasmodic effect at the rat ileum. ${ }^{35}$

\section{The Role of Gingerol and Shogaol in the Pharmacology Activity of Ginger}

Polyphenols are an important class of antioxidant defense. ${ }^{22}$ The metabolites of ginger have recognised as potent anti-oxidants due to their ability to inhibit the oxidation of various free radicals and the production of nitric oxide. The pharmacology activities of gingerol and shogaol are related with their possible mechanisms of action and structure-activity, as elucidated through selected in vitro and in vivo models. $^{23}$

Gingerol and shogaol which show anticancer activity against a lot of cells, metabolism of ginger found mutagenic. Metabolites against various carcinomas and cell lines of lung, colon, skin, pancreas, prostate, liver, ovarian, colon, breast, kidney. ${ }^{23}$

[6]-gingerol is endowed with strong antioxidant activity both in vivo and in vitro, in addition to strong anti-inflammatory and antiapoptotic actions. ${ }^{16}$ [6]-Gingerol has been found to possess various pharmacological and physiological effects including analgesic, antipyretic, gastroprotective, cardiotonic, and antihepatotoxic activities. Gingerol also has a potent inhibitory effect on prostaglandin biosynthesis. ${ }^{18}$ The [6]-gingerol is the most phytocompound potent against cancer compared with the other ginger ligands like [8]-gingerol, [10]-gingerol and [6]-shogaol. The next research can be focused to develop 6-gingerol. ${ }^{31}$

\section{Side effect}

In generally $Z$. officinale is considered safe for use. There is a slight risk of toxicity in normal doses, but some people may have indigestion. $Z$. officinale can also cause contact dermatitis in sensitive individuals. $Z$. officinale reported to cause severe hyperkalemia in patients with cirrhosis. Use ginger with caution in people with liver disorders or liver disease who have been exposed before. ${ }^{37}$

\section{Toxicity}

Acute toxicity studys with oral single dose of $Z$. officinale rhizome $(2000 \mathrm{mg} / \mathrm{Kg}$ and $2500 \mathrm{mg} / \mathrm{Kg}$ ) were observed for 14 day on rats, no death was found. $L D_{50}>$ $2000 \mathrm{mg} / \mathrm{Kg}$ and $\mathrm{LD}_{50}>2500 \mathrm{mg} / \mathrm{Kg} .^{36}$

Sub acute toxicity study with fine powder of $Z$. officinale rhizome (up to $2000 \mathrm{mg} / \mathrm{kg} /$ day) were administered orally to male and female rats for a duration 35 days showed no toxic effect. ${ }^{36}$

\section{Dosage}

Ginger doses generally are 1-4 g per day, taken in divided doses. ${ }^{38}$ To prevent motion sickness: $0.5 \mathrm{~g}, 2-$ 4 times daily in adults and children more than 6 years and for dyspepsia: 2-4 g daily, as powdered plant material or extracts. ${ }^{36,37}$

\section{Conclusions}

Z. officinale var. rubrum is considered a safe herbal remedy with only slight and not significant adverse effects. This plant is potential to be developed for future phytomedicine, however it needs further explorations on its clinical studies in humans is expected, especially the efficacy and safety of the risk of side effects. 


\section{References}

1. Wang J., Ke W., Bao R., Hu X., dan Chen F., (2017): Beneficial effects of ginger Zingiber officinale Roscoe on obesity and metabolic syndrome: a review, Ann. N.Y. Acad. Sci. ISSN, 0077-8923. Doi: 10.1111/nyas. 13375

2. Langner E, Greifenberg S, Gruenwald J., Ginger: History and Use. Adv Ther. (1998): Review. PubMed PMID: 10178636.

3. Dhanik J., Arya N. and Nand V., (2017): Review on Zingiber officinale. Journal of Pharmacognosy and Phytochemistry. 6(3): 174-184

4. Septi Muharni dkk. (2013): Efek Penggunaan Suplemen Ekstrak Daun Jambu Biji (Psidium guajava Linn.) dan Angkak (Monascus purpureus) dalam Meningkatkan Trombosit pada Demam Berdarah Dengue (DBD) di Instalasi Rawat Inap IImu Penyakit Dalam RSUP. DR. M. Djamil Padang. Jurnal Penelitian Farmasi Indonesia.

5. Elfahmi, Ruslan K., Bos R., Kayser O., Woerdenbag H.J., Quax W.J., (2006): Phytochemical and Biosynthetic Studies of Lignans, with a Focus on Indonesian Medicinal Plants.

6. Grzanna R, Lindmark L, Frondoza C. Ginger. (2005): A Herbal Medicinal Product with Broad Antiinflammatory Actions. Journal of Medicinal Food. $8(2): 125-132$

7. Ghasemzadeh A., Jaafar H. Z. E., Rahmat A, (2016): Variation of the Phytochemical Constituents and Antioxidant Activities of Zingiber officinale var. rubrum Theilade Associated with Different Drying Methods and Polyphenol Oxidase Activity, Molecules, 21, 780; Doi:10.3390/molecules21060780

8. Kumar G., L. Karthik, K. V., Rao B., (2011): A Review on Pharmacological and Phytochemical Properties of Zingiber officinale Roscoe (Zingiberaceae). Journal of Pharmacy Research. 4(9),2963-2969

9. Ghasemzadeh A., Jaafar H. Z. E., Rahmat A., Wahab P. E. M. and Halim M. R. A. (2010): Effect of Different Light Intensities on Total Phenolics and Flavonoids Synthesis and Anti-oxidant Activities in Young Ginger Varieties (Zingiber officinale Roscoe) Int. J. Mol. Sci. 11, 3885-3897; Doi:10.3390/ijms11103885

10. Forouzan S., Bahmani M., Parsaei P., Mohsenzadegan A., Gholami-Ahangaran M., Sadeghi E., Saki K., and Delirrad M. (2012): AntiParasitic Activites of Zingiber officinale Methanolic Extract on Limnatis Nilotica. Global Veterinaria. 9 (2): 144-148

11. Mishra R. K., Kumar A. and Kumar A. (2012): Pharmacological Activity of Zingiber officinale. International Journal of Pharmaceutical And Chemical Sciences Vol. 1 (3) Jul-Sep 2012

12. Bhargava S., Dhabhai K, Batra A, Sharma A, Malhotra B. (2012): Zingiber Officinale: Chemical And Phytochemical Screening And Evaluation Of Its
Antimicrobial Activities. Journal of Chemical and Pharmaceutical Research, 4(1):360-364

13. Ho S-C., Chang K-S., Lin C-C. (2013): AntiNeuroinflammatory Capacity Of Fresh Ginger Is Attributed Mainly To 10-Gingerol. Food Chemistry 141 3183-3191. http://dx.doi.org/10.1016/j.foodchem.2013.06.01 0

14. Sukarman. (2013):. Production and Management of White Big Ginger (Zingiber officinale) Through Seed Industri. Jurnal Litbang Pertanian Vol 32 No. 2 Juni $2013: 76-88$

15. Kepmenkes. (2011):. Formularium Obat Herbal Asli Indonesia. Hal 48

16. P Anasori1 and G. Asghari. (2008): Effects of Light and Differentiation on Gingerol And Zingiberene Production In Callus Culture of Zingiber officinale Rosc. Research in Pharmaceutical Sciences. April 2008; 3(1): 59-63

17. Ghasemzadeh A., Jaafar H. Z. E., and Rahmat A.(2010): Synthesis of Phenolics and Flavonoids in Ginger (Zingiber officinale Roscoe) and Their Effects on Photosynthesis Rate Int. J. Mol. Sci. 11, 45394555. Doi:10.3390/ijms11114539

18. Bhattarai S., Tran V. H., and Duke C. C. (2001): The Stability of Gingerol and Shogaol in Aqueous Solutions. Journal of Pharmaceutical Sciences. Vol. 90, 1658-1664

19. Hoque M. A., Bala B. K., Hossain M. A. and Uddin M. B. (2013): Drying Kinetics Of Ginger Rhizome (Zingiber Officinale). Bangladesh J. Agril. Res. 38(2): 301-319.

20. Garace S., Sankari M., and Gopi. (2017): Antimicrobial Activity of Ethanolic Extract of Zingiber Officinale - An in vitro Study. U. Santo Grace et al /J. Pharm. Sci. \& Res. Vol. 9(9), 14171419

21. Islam M. S., Mia M., Apu M. A. I., Halder J., Rahman M. F., Islam M., and Jahan N. (2015): A Comprehensive Review On Region Based Traditional Ayurvedic Practitioner's Plants Secondary Metabolites And Their Phytochemical Activities In Bangladesh. Journal of Pharmacognosy and Phytochemistry, 3(6): 202-216

22. Andriyani R., Budiati T. A., and Pudjiraharti S. (2015): Effect of Extraction Method on Total Flavonoid, Total Phenolic Content, Antioxidant and Anti-Bacterial Activity of Zingiberis officinale Rhizome. Procedia Chemistry 16, $149-154$

23. Semwal R. B., Semwal D. K., Combrinck S., and Viljoen A. M. (2015): Gingerols and Shogaols: Important Nutraceutical Principles From Ginger. Phytochemistry. http://dx.doi.org/10.1016/j.phytochem.2015.07.0 12

24. Marx W., McKavanagh D., Alexandra L. McCarthy3, Bird R., Ried K., Chan A., and Isenring L. (2015): The Effect of Ginger (Zingiber officinale) on Platelet 
Aggregation: A Systematic Literature Review. Plos One. DOI:10.1371/journal.pone.0141119

25. Mošovskáa S., Novákováa D., Kaliňák M. (2015). Antioxidant Activity Of Ginger Extract And Identifcation of Its Active Components. Acta Chimica Slovaca. Vol. 8, No. 2, 2015, pp. 115-119, DOI: 10.1515/acs-2015-0020

26. McKay DL, Chen CY, Zampariello CA, and Blumberg JB (2015): Flavonoids and Phenolic Acids from Cranberry Juice are Bioavailable and Bioactive in Healthy Older Adults. Food Chem 168: 233-240

27. Shidfar F., Rajab A., Rahideh T., Khandouzi N., Hosseini S. and Shidfar S. The Effect Of Ginger (Zingiber officinale) On Glycemic Markers In Patients With Type 2 Diabetes. J Complement Integr Med. 12(2): 165-170.

Doi 10.1515/jcim-2014-0021

28. Ghasemzadeh A, Jaafar H.Z.E and Rahmat A. (2015): Optimization Protocol For The Extraction Of 6-Gingerol And 6-Shogaol From Zingiber officinale Var. Rubrum Theilade And Improving Antioxidant And Anticancer Activity Using Response Surface Methodology. Bio Med Central.

Doi 10.1186/s12906-015-0718-0

29. Sutardi L. N., Wientarsih I., Handharyani E., Andriani, Setiyono A. (2015): Indonesian Wild Ginger (Zingiber sp) Extract: Antibacterial Activity Against Mycoplasma gallisepticum. IOSR Journal Of Pharmacy. Volume 5, Issue 10. PP. 59-64

30. Nazish I., Ansari S. H., Arora P., Ahmad A. (2016): Antiobesity Activity of Zingiber offcinale. Pharmacogn. J.;8(5):440-446

31. Kumara M., Shylajab M.R., Nazeemc P.A., Babu T. (2017): 6-Gingerol is the Most Potent Anticancerous Compound in Ginger (Zingiber officinale Rosc.) Journal of Developing Drugs. DOI: 10.4172/2329-6631.1000167
32. López E. I. C., Balcázar M. F. H., Mendoza J. M. R., Ortiz A. D. R., Melo M. T. O., Parrales R. S., Delgado T. H. (2017): Antimicrobial Activity of Essential Oil of Zingiber officinale Roscoe (Zingiberaceae). American Journal of Plant Sciences.

33. https://manfaatjahemerah.com/perbedaan-jahemerah-jahe-gajah-dan-jahe-emprit/

34. Marwat, K.S., Shoaib, M., Khan, A.E., Rehman, F., Ullah, H. (2015) : Phytochemistry and Bioactivities of Quranic Plaant, Zanjabil-Ginger (Zingiber officinale Roscoe): A Review. American-Eurasian J. Agric \& Environ. Sci. Pakistan; 707-713

35. Riyazi A, Hensel A, Bauer K, Geissler N, Schaaf S, Verspohl E. (2007). The effects of the volatile oil from ginger rhizomes (Zingiber officinale), its fractions and isolated compounds on the 5-HT3 receptor complex and the seratoninergic system of the rat ileum. Plant Med.

36. Malaysian Herbal Monograoh; Halia Rhizome Zingiber officinale Roscoe. (2015).(http://www.globinmed.com/index.php?op tion=com_content $\&$ view=article\&id=102052:zingi ber-officinale-rosc\&catid=209\&/temid=143), diunduh pada 14 Maret 2018.

37. Zingiber officinale Roscoe. (http://www.globinmed.com/index.php?option=c om_content\&view=article\&id=106082:zingiberofficinale-roscoe \&catid=286: medicinal-herbsplants-database\&ltemid=357), diunduh pada 14 Maret 2018.

38. Monograph Zingiber officinale. (2003). Alternative Medicine Review. Volume 8, Number 3. Page 331335 